\title{
POLITICS AND TOURISM DEVELOPMENT: THE CASE OF NORTHERN PROVINCE - SRI LANKA
}

\author{
Sivesan.S \\ Department of Marketing, Faculty of Management Studies and Commerce, \\ University of Jaffna - Sri Lanka, sivesanuni@yahoo.com
}

\begin{abstract}
The concept of tourism development has become the focus of increasing attention among tourism practitioners and scholars alike. Little research, however, has been undertaken to investigate the relationship between politics and tourism development in Sri Lanka from the perspective of stakeholders. The main objective of this study is to explore the relationship between politics and tourism development in Northern Province - Sri Lanka. Drawing on study in Northern Province in Sri Lanka, it reveals the ways in which political instability and political interferences have viewed as major obstacles to tourism development. Further, this study concludes that stakeholders, including the state, the provincial authorities and investors, have a willingness to promote the industry. This study offers meaningful information for developing strategy on the part of tourism management in the absence of political interferences.
\end{abstract}

Key words: tourism development; Sri Lanka; political instability; liberalize economic policy

\subsection{Introduction}

Tourism in Sri Lanka is one of the faster growing industries, and was the fourth largest foreign- exchange earner in 2015 (Sri Lanka Tourism Development Authority, 2016). Over the last four decades, however, growth of this industry fluctuated due to political unrest. This notion is accepted by Sri Lankan researchers Samaranayake, Lantra, and Jayawardena (2013, p. 424), pointed out that " the biggest challenge Sri Lanka has faced since independence was the ethnic war that commenced in 1983 arising from demands for an independent state (known as Tamil Eelam ) by a militant Tamil group-Liberation Tigers of Tamil Eelam (LTTE)". Many researchers including

Hall (1994), Richter (1999), Robinson (2008), and Samaranayake (2012), who emphasised that the difficulties of tourism development in developed countries and developing countries arising from the political power struggle among different stakeholders. In Sri Lanka, last thirty years Civil War and politcal instability have become critical issues in development of the tourism industry. This study is an attempt to investigate the association conceptually and emparically, between the concept of politics and tourism development in Northern Province. For this study a qualitative approach has been used. This approach works best for understanding social phenomena. 


\subsection{Research Direction}

\subsection{Research Context Territory}

Northern is situated in the North region in Sri Lanka. Administratively, Northern Province, which consisting of five districts namely Jaffna, Kilinochchi, Mannar, Mullaittivu and Vavuniya, comprises one municipal council, five urban councils and 28 Pradeshiya Sabhas. Northern Province boundaries are Gulf of Mannar and Palk Bay to the West, Palk Strait to the North, Bay of Bengal to the East, Eastern, North Central and North Western provinces to the South. Northern Province covers about $14 \%$ of the land mass of Sri Lanka. Its total extent, around $8,849 \mathrm{Sq} . \mathrm{km}$ and around $40 \%$ of Sri Lanka's coastal area is within this province. The distance from Talaimannar to Rameswaram in Southern India is just 35 kilometres. Northern Province as a tourist destination has more significant cultural heritage, natural heritage and historical landscape.

As noted above, Northern Province played and still plays a vital role in Sri Lankan Tamil history and cultural heritage. Sri Lankan historians including Sitrampalam (2005), Siriweera (2002) and Pathmanathan (1978) articulated that Northern Province has a strong historical background. That can be understood through colonial and precolonial monuments and cultural heritage destinations. The ancestors who lived in Northern territory during historical periods have inherited arts, buildings, traditions and beliefs expressing the culture of the societies which have been passed down from preceding generations. This is in line with previous research findings. For example, Millar (1989, p. 9) observes that "heritage sites provide the tangible links between past, present and future". The attributes or immaterial possession that is inherited from ancestors could be identified as heritage belonging to the particular historic environment. The character, identify and cultural variety build up the heritage of an area. The heritage inherited from past generation should be maintained in the present time and has to bestow for the benefit of future generations. Since the heritage remains within the Northern Province depict the multi-cultural mutual heritage of Sri Lanka which is not identified in other parts of Sri Lanka. It is the duty of the present generations to conserve and hand over to the future generations in order to educate the societies of the existence of multi-cultural societies in the past. In the Northern Province, heritage sites and buildings can have a very positive influence on tourism development as well as on many aspects of the way a community develops. Northern Province as a tourist destination has many historical and cultural heritage sites. Those are interconnected with ancient Jaffna Kingdom and colonial era. Broadly speaking, regeneration, housing, education, economic growth and community engagement are examples of the ways in which heritage can make a very positive contribution to community life.

\subsection{Investigation Framework of the Study}

For this study a qualitative approach has been used. This approach works best for understanding social phenomena 
(Remler \& Van Ryzin, 2010; Ritchie \& Spencer, 2002; Snape \& Spencer, 2003). This study deals with various stakeholders. Researcher, therefore, understood that field visit based interviews is the best way to collect appropriate information for this study. This study has been developed based on primary and secondary data. Secondary data has been derived through document analysis of relevant documents such as annual reports of Sri Lanka Tourism Development Authority and Northern Province. Document analysis is a sophisticated data collection method. It is mostly used in qualitative research (Rasmussen, Muir-Cochrane, \& Henderson, 2012). This is consistent with other researchers including Chandralal (2010) and Cheer, Reeves, and Laing (2013) who have also used qualitative methodological approaches for data collection and analysis in order to gain the views of different interested parties. During the period from July to October 2016, data was collected through field-based in-country interviews throughout Sri Lanka. This approach enabled a discourse analysis methodological approach to interviewees. This meant that respondents were able to discuss their thoughts on the role of tourism in Northern Province and also long term approaches for sustainability. The interviews also enabled more extended responses where interviewees discussed their experiences, attitudes and understanding of the development of tourism from political and economic framework in the Northern Province of Sri Lanka. For this study purposive sampling technique has been employed. The sample size of interviewees was 18 and the format was that of semi-structured interviews undertaken with key stakeholders. All interviews were recorded on i-phone and all voice records were transcribed in verbatim (word for word) format soon after completion of interviews.. Interviews have been conducted with international (one) and domestic tourists (two), host communities (two), civil servants (three), hotel operators (two), Politicians (three), provincial level tourism development officers (two), academic (one), and members of Sri Lanka Tourism Development Authority and Sri Lanka Promotion Bureau (two). A cording scheme was derived based on the interview schedule. To identify key themes, the transcripts were read several times (Miles \& Huberman, 1994). Discourse analysis was used to address the research problem. In addition to that, some original text was cross - referenced.

\subsection{Understanding Correlation between Politics and the Development of Tourism in Sri Lanka}

Although, political influence in developing world is stronger than in most developed countries and in many instances is extremely overwhelming. Hall (1994, p. 2) argues that "the relationship between politics and tourism is not primarily concerned with political parties and election and their influence on tourism policy although this is of course, an aspect of political tourism". In the case of Sri Lanka, many scholars, including Guruge (2009), Jayawardena, Richard Teare, and Jayawardena (2013), Richter (1999), Robinson (2008), Samaranayake (2012) and Samaranayake et al. (2013) shared that there is a strong connection 
between political environment and tourism development. Importantly, policies of political parties are mostly influencing upon the development of tourism industry because, according to the political constitution ( $13^{\text {th }}$ amendment), the tourism industry is considered as a concurrent subject. This means that both national and provincial governments are able to take part independently in sustainable tourism development. Before the analysis, answer to the following question should be found. "When did tourism begin in Sri Lanka? An answer can be that even thousand years ago pilgrims had started arriving in Sri Lanka (Karunaratna, 1999). Historically, British took an initial step to develop tourism industry in Sri Lanka. The establishment of the Tourist Bureau (TB) in Sri Lanka in 1937 is evidence of it. Its functions, however, were clogged by Second World War (Central Bank of Sri Lanka, 1998; Samaranayake, 2012).

In fact, after the Second World War, tourism industry throughout the world became a popular industry (Nordström, 2005). The first post-independence Sri Lankan government failed to give more substantial attention to development of tourism, despite the fact that during this period, significant growth in international tourism was experienced by other Asian countries (Attanayake, Samaranayake, \& Ratnapala, 1983, p. 243). During this era, in the case of tourism development, physical infrastructure, including transport services and accommodations, were necessary to attract international tourists and international investment. Tourist arrivals to the island, in fact, are stagnated around 19,000 per annum until 1956. During that period, there was no clear tourism planning and policy at all and no quite travel research being conducted (Central Bank of Sri Lanka, 1998). Ediriweera (1969, p. 23) pointed out that in 1946 not only most host communities, but also government itself has seen tourism as a "big joke". Subsequently, tourism industry has received less attention. Leftist government, which was in power from 1956 to 1965, adopted the import substitution strategy. In this period, a lack of marketing propagandas and limited destination development programmes were carried out (Guruge, 2009). In 1965, with the election of the United National Party, an export oriented policy was implemented. The centre-right government (the United National Party) came to power in 1966. It had a broader concept about industrial development, particularly the tourism industry. Attanayake et al. (1983) noted that since 1966, government perception with regard to tourism is politically and economically changed. In 1967, the first long term 10-years master plan was implemented with objective of achieving optimum growth in international travel and tourism.

Through implementation of the Ceylon Tourist Board Act (No. 16 of 1966), this industry has received a statutory authority framework. In 1966, with the birth of the Ceylon Tourist Board, this industry became a very significant economic driver (Guruge, 2009). This body replaced the Ceylon Tourist Board Act (No. 16 of 1966), which, even with a 'Six Year Plan' in 1954, had failed to produce noticeable 
growth (Due, 1980). Two years later the Tourist Development Act (No. 14 of 1968) was introduced allowing the Tourist Board to regulate the provision of tourist services. Government in this period established the Ceylon Hotel School, which produced effective and efficient human resource to the industry. More significantly, the establishment of the Ceylon Tourist Board is an important landmark in the history of institutional tourism, which paved the way for rapid development of the industry. During that period, mass tourism was developed and tourist traffic to the all island reached a level of 153,665 in 1977. From 1971 to 1977, the Sri Lanka Freedom Party was in power. That government adopted closed economic policy. Foreign and domestic investment on tourism declined compared with previous government's period. However, during this period, the tourist arrivals showed a positive but decelerated growth from 1972, mainly because of the recreation in Western Europe which was the major source of touristic traffic to country. The global energy crisis in 1974 worsened the situation. Unfortunately, these external events occurred at a time when the capacity of industry was expanding. The year 1977 was a landmark in the economic and social policies of the post- independence period. Farreaching policy reforms were introduced in that year to shift the focus from an inward looking development strategy to an outward looking development strategy to free the economy from an array of controls. Having realized the benefits of liberal economic policies, the two main political parties have come to accept market oriented policies, thereby reducing the risks of frequent policy changes in government (Powell, Cuschnir, \& Peiris, 2009; Ratnapala, 1999; Robinson, 2008). The arrivals showed higher growth from 1977 with improved international transport facilities and the positive impact of the open economic policy package introduced in 1977. The liberalization impacted not only on economic benefit of the tourism industry but also impacted on cultural heritage preservation strategy. For example, during this period, government took initial steps to protect cultural heritage sites throughout the island. As a result, the Cultural Triangle is an international cultural heritage preservation programme commenced in 1980 in collaboration with the United Nations Educational, Scientific and Cultural Organization. This conservation campaign covered six destinations: Abhayagiri Monastery; Jetavana Monastery; Alahana Pirivena; Sigiriya Rock Fortress, Boulder and Water Gardens: Dambulla painted caves; and Kandy and its cultural complex (De Silva, 1981). Economic view, the liberalization of impacts and foreign exchange gave further impetus to the growth of the industry and tourist arrivals in 1982 had grown to 407,230 . The arrivals declined sharply in 1983 in due to ethnic conflict and political instability. In other words, in fact, during the first phases of Civil War held from 1983 to 1987 tourist arrivals declined to a large extent. As a result, the country was unable to reap the full benefits of the economic recovery. In Western Europe the adverse publicity resulting from the security situation in the country and competition from other locations in the region, such as the Maldives, badly affected the industry. 
In 1987, the Indian government acted as intermediary to initiate the peace talk between the Sri Lankan government and the LTTE. In the mid-year of 1988, twin wars began between the Indian Peace Keeping Force (IPKF) and the LTTE. As a result, tourism industry faced more problems. In 1990, the second peace talk was started between government and the LTTE. In 1990, tourist arrivals increased from 182,620 in 1987 to 297,888 in 1990. In 1992, the Second Master Plan (1992 - 2001) was implemented. During this period, the tourism industry encountered many political challenges. After the assassination of the president of the country in 1993, a new government the People Alliance a coalition led by SLFP, LSSP, and CP came to power in 1994. This government committed to promote industrial sectors including the tourism industry, and started the third peace talk with LTTE which was not successful. As a result, the third phase of Civil War commenced. Many Tamil civilians were killed and properties were destroyed by the Sri Lankan militaries. Many countries, including United States, United Kingdom and Australia, advised their citizens to avoid going to Sri Lanka. Tourist arrivals to the island declined and in this year, the industry was severely affected by the bombing of the Central Bank of Sri Lanka. In 2002, the United National Party came into power and resumed the peace talk with the mediation of Norway. During the period from 2002 to 2006 , peace talk was being proceeded. During this period, the tourism industry was revitalized through the penetration of large amount of investment on the tourism industry. Moreover, tourist arrivals to the country boomed greatly and reached a level of 559,603 in 2006. In 2007, the fourth phase of Civil War (final war) broke out and lasted until $19^{\text {th }}$ of May 2009. In this era, the arrival displayed a negative growth rate from 2007 to 2009, mainly because of the pathetic political situation in the Northern Province. After the Civil War, the capacity of the industry continues to expand in terms of marketing opportunity and investment. In fact, post-war figures demonstrate that the Sri Lankan tourism industry is significantly revitalized and it became more important faster growing industry. It reached the highest numbers of tourist arrivals $(1,798,380)$ in 2014. As mentioned above, the aftermath of Civil War in 2009, new chapter in the tourism industry throughout Sri Lanka commenced. Many national and international investors committed to invest on the industry. As a result, the supply of accommodation in Sri Lanka particularly in South and Central part of Sri Lanka have experienced important boom over the last seven years. The growth of accommodation, however, is very low in Northern Province compared with other areas in Sri Lanka. Based on the information obtained from the SLTDA and field-based in-country interviews there are three hotels, thirty eight guesthouses and thirteen restaurants have which registered with the SLTDA. During the last two years there was drastic improvement in the number of SLTDA registered tourist establishments in the NP. There should be continuous awareness campaigns to educate any tourism service providers to obtain the approval of the SLTDA. It is estimated that there are with the capacity of 805 rooms in 72 hotels, guest houses 
and accommodation units.

\subsection{Mapping Politics and the Development of Tourism in Northern Province}

Throughout field visit -interview, an ongoing argument addressed how political issues can be restructured in regard to tourism development. Tourism has been included under the concurrent subject. The concurrent subject is usually carried out by the central and the provincial government. Thus both the central and provincial governments are mandated to contribute to the development of the tourism industry. However this system has some practical problems in the implementation of process. The administrative system at a local level is complicated because there is a lack of coordination between provincial and central government. In the tourism development process, central government institutions (district and divisional secretariat) and, provincial level organizations (municipal, urban council and Pradeshiya Sabha) should work together. Politically, both central and the Northern Provincial government may have different thoughts about tourism development in the Northern Province. Interviewees confirmed that anti Tamil sentimentalists and religious extremists have either directly or indirectly had an influence on political decision-making as well as tourism development in Sri Lanka. In reality, politics is strongly biased by Buddhist extremists, who can sometimes create adverse issues in not only sustainable heritage tourism but also all aspects of development. This is in line with previous researchers' findings, De $\operatorname{Votta}(2007$, p. 12) noted that "the problem for Buddhists is that even as monks have become increasingly involved in politics, the concomitant forces of modernization and their attendant materialistic culture have in turn corrupted the monks". One interviewee pointed that:

[p]olicies opposed to Tamil and other religions (with the exception of Buddhism) have become a fundamental reason for violence and radicalization in Sri Lankan tourist destinations. (R4)

In this research, the content of the above statement is attested to by the following incidents: in the radicalized Civil War period, tourists could not enter into some heritage tourist destinations due to security constraints and, in 2014, a boycott of Halal products imported and used in hotels and restaurants disrupted the tourist trade. Similarly, previous Sri Lankan researcher Munasinghe (2015) indicated that political and religious interference in developing countries particularly in Sri Lanka has a great impact on tourism development.

Analysis of legal documents and fieldvisit interview response confirms that the authority and responsibilities of national government organizations are greater than those of provincial and district-level agencies. Most of the time, regional-level government's institutions are expected to implement the national-level tourism development plan (Samaranayake, 2012). Many interviewees felt that, on several occasions, the attention of this organization with regard to the development of tourism in Northern Province has been misplaced. In addition, the central government has not allocated the funding that many provincial 
governments, including the Northern Province, expected, to implement the development plan. For key stakeholders the main issues of tourism development are:

[a] lack of human resources, limited peak season accommodation capacity, budget constraints as well as a lack of coordination between the private and public sector ... and ineffective government process. (R7)

The Tourism Promotion Bureau is another organization tasked with opening markets for Sri Lankan tourism destinations through the implementation of effective promotional plans. Interview data confirmed that the SLTPB is strongly involved in many promotional activities such as travel fairs, road-shows and outdoor promotional activities. The SLTDA has linkages with many international tourism advertising agencies and has launched a new heritage tourism venture, the Ramyanam package, to attract Asian tourists (Sri Lanka Tourism Promotion Bureau, 2011). There are many sites in Sri Lanka that are related to the Ramyanam, a well-known ancient Indian myth. The Indian government is keen to promote Ramayanam Trail package in Sri Lanka, particularly in Northern Province. Hence some interviewees suspected that through promotion of this Ramayanam Trail package, Indian government may expand their political activities in Northern Province.

Present-day, all the provincial councils (nine) and central government of Sri Lanka have opened their doors to promote domestic and international tourism, not only as a means of economic and social development, but also as part of country's economic policies. A senior politician, in an interview indicates:

[t]ourism development in Sri Lanka has been received a positive attention since the colonial era, with the hope of earning foreign exchange but tourism is relatively novel to Northern Provincial. (R2)

Despite, a lack of priority to tourism development in Northern Province has been given because the people in the NP believed that tourism has possibility to create anti - social effects such as prostitution and drugs. In Civil War period, tourism industry in Northern Province was totally destroyed. Further, field-based interviews confirmed that tourism planning and policy in Northern Province is connected with Sri Lankan economic and political issues, with most respondents suggesting that, in terms of tourism policies and planning, there has been a lack of consideration of regional economic policies and situations. In general, the Northern Province economy is agricultural, based on products including paddy and onion cultivated in NP and its surrounding areas. Therefore many respondents were expecting that, importantly, tourism policy and planning should be taken into account with regional economic sectors. In fact, the aim of sustainable tourism can only be achieved if it is considered within regional, national and international political and economic situations.

Immediately after peace being restored in mid-2009 there is a large influx of 
domestic and international tourists to NP. Domestic tourists from southern territory of Sri Lanka, pay more attention to visits the War Zone, because over the last four decades, Civil War was held between representatives of Tamil community (the Liberation Tigers of Tamil Eelam (LTTE) and the government. Finally, in May 2009, the government won the Civil War. As a result, many majority community people (Sinhala community) have interest to learn war memories from battlefield. Such intention is not new. Australian researchers Logan and Reeves (2008: 4) provide the justifications for growth of post war tourism in their book Places of Pain and Shame Dealing with Difficult Heritage indicates "governments, military groups and people who lost family members and close friends in wars over last century have interest in keeping memories alive, and war related tourism to places like Flanders has grown enormously in recent decades". Northern Province as a tourist destination has a substantial demands from domestic tourists, Diaspora (migrated local people) and international tourists. In fact, several local people, who migrated to overseas countries, are now visiting the NP to see their relatives and friends. An executive civil servant in the interview mentions,

[W] hen filling vacancies in tourismrelated government organizations, politicians frequently recommend their supporters. Moreover, the Sri Lankan Tourism Act 38 of 2005 allots the tourism minister power to make the final decision about all tourism-related activities, and also to appoint the director and chairperson of key tourism-related government organizations. This is a good example of legally sanctioned political intrusion into tourism administration. (R11)

Whoever the final policy decisionmaker might be is not a major matter but that decisions taken should be unbiased and appropriate to the tourism development of the nation. Historically, many disagreeable experiences occurred through political interference in administrative affairs.

\subsection{Conclusion}

This study explored several issues including post-war tourism development; linkage between the development of tourism and political mechanism in war affected areas particularly in the Northern Province, and the perceived impact of historical and cultural heritage monuments on tourism development in Northern Province-SriLanka. Sri Lankan political development has experienced more challenges to develop the industry than opportunities in the last five decades. From the time of independence to 1977 , Sri Lankan ruling political parties adopted various and complicated political policies that generated a serious negative impact on national and regional development (Aslam \& Awang, 2015). Even though, the issues of political instability and Civil War were at the forefront of tourism and economic development until 2009 (Reeves \& Sivesan, 2017). After Civil War, tourism industry has been revived to a better state. Tourism industry helps the Sri Lankan community to have employments and income. Stakeholders view tourism as most significant foreign 
exchange earning tool, promoter of social cultural identity of the host communities, job generators poverty controllers and guardian of historical and heritage monuments. This study has examined this proposition by considering cultural heritage, political, and economic issues. This discussion is important to understand nature of tourist destination. Finally, maintaining the thriving tourism industry in a sustainable manner is a key challenge in war affected areas. The central and provincial governments have to pay attention to develop sustainable tourism plan with collaboration of various stakeholders at different levels. This study suggests some insights to productively improve the administrative structure. As discussed throughout this study there is no separate tourism organization within the Northern Province therefore, the Northern Province should initiate the establishment a provincial Tourism Development Bureau. The national and provincial government needs to pay attention to development of a reliable destination management framework with collaboration of stakeholders. Through this, mutual understanding between both central and provincial bodies can be build up. Furthermore, the consistency and sequence in the economy and tourism policy should be adopted. In many cases, ruling political parties have changed policies and planning, for their convenience and with hidden agendas, to the detriment of the developing tourism industry. Further, tourism policy and planning should focus on long standing sustainable tourism rather than tourism promotion. It is now time that the Northern Province and the SLTDA should work together to the sustainable destination development in the five districts. The tourism sector should be considered as an independent sector, and allowed to develop a competitive tourism market free from of political and religious interference. The decision- making power in tourism development is centralized, perhaps too much so. As comes under the thirteenth amendment to the constitutions it is hard to make changes because in the Sri Lankan parliament a two- thirds majority is required. In fact, such change is not possible in the Sri Lankan political climate. The SLTDA, therefore, can make policy - based decision to liberalize decision- making activities through an appropriate participative management framework which is enabled by the tourism Act, No.38 of 2005(Sivesan, 2012). The management model of the SLTDA and SLTPB are structurally welldesigned with stakeholder collaboration and inter- organization coordination. That should be practiced, with power delegation and definition of the responsibilities of participants. This type of participative governance model is supported by many academics (Adu-Ampong, 2014; Alipour et al., 2011; Bramwell, 2010, 2011; Bramwell et al., 2011; Bramwell et al., 1999). 


\section{References}

1. Adu-Ampong, E. A. (2014). Divided we stand: institutional collaboration in tourism planning and development in the Central Region of Ghana. Current Issues in Tourism, $1-20$.

2. Alipour, H., Vaziri, R. K., \& Ligay, E. (2011). Governance as catalyst to sustainable tourism development: Evidence from North Cyprus. Journal of Sustainable Development, 4(5), 32.

3. Aslam , M., \& Awang, K. W. (2015). Enterprising rural tourism for sustainable rural development in Sri Lanka. International Journal of Economics and Financial Issues, 5(1).

4. Attanayake, A., Samaranayake, H. M. S., \& Ratnapala, R. (1983). Sri Lanka. In E. Pye \& T. Lin (Eds.), Tourism in Asia: The economic impact (pp. 241-351). Ottawa: Singapore University Press for International Development Research Centre.

5. Bramwell, B. (2010). Participative planning and governance for sustainable tourism. Tourism Recreation Research, 35(3), 239-249

6. Bramwell, B. (2011). Governance, the state and sustainable tourism: a political economy approach. Journal of Sustainable Tourism, 19(4-5), 459-477.

7. Bramwell, B. (2015). Theoretical activity in sustainable tourism research. Annals of Tourism Research, 54, 204-218.

8. Bramwell, B., \& Lane, B. (2011). Critical research on the governance of tourism and sustainability. Journal of Sustainable Tourism, 19(4-5), 411-421.

9. Bramwell, B., \& Sharman,A. (1999). Collaboration in local tourism policymaking. Annals of Tourism Research, 26(2), 392-415.

10. Central Bank of Sri Lanka. (1998). Economic progress of indepent Sri Lanka. Colombo: Central Bank of Sri Lanka.

11. Chandralal, K. P. L. (2010). Impacts of tourism and community attitude towards tourism: A case study in Sri Lanka. South Asian Journal of Tourism and Heritage, 3(2), 41-49.

12. Cheer, J. M., Reeves, K. J., \& Laing, J. H. (2013). Tourism and traditional culture: Land diving in Vanuatu. Annals of tourism research, 43, 435-455.

13. De Silva, K. M. (1981). A history of Sri Lanka: Univ of California Press.

14. De Votta, N. (2007). Sinhalese Buddhist nationalist ideology: Implications for political and conflict resolution in Sri Lanka. Washington: East - West Centre Washington.

15. Due, E. (1980). Tourism and development: Examining the case of Sri Lanka. (Master of Arts), McMaster University

16. Ediriweera, P. A. (1969). Changing patterns in Tourism Economic Review, 5(3), 19-27.

17. Guruge, G. K. (2009). Impact of international tourism on peripheral regions the case of Sri Lanka. Colombo: University of Kelaniya. 
18. Hall, M. C. (1994). Tourism and politics: policy, power and place: John Wiley \& Sons.

19. Jayawardena, Richard Teare, C., \& Jayawardena, C. (2013). Innovative solutions for future tourism development in Sri Lanka (2013-2026). Worldwide Hospitality and Tourism Themes, 5(5), 512-531.

20. Karunaratna, N. (1999). Kandy past and present. Colombo: Central Cultural Fund.

21. Logan, W, \& Reeves, K.(2008) Introduction: Remenbening places of pain and shame. In W.Logen \& K.Reeves (Eds.) places of pain and shame Dealing with difficult heritage united kindom: Routledge.

22. Miles, M. B., \& Huberman, A. M. (1994). Qualitative data analysis: A sourcebook. Beverly Hills: Sage Publications.

23. Millar, S. (1989). Heritage management for heritage tourism. Tourism Management, 10(1), 9-14.

24. Munasinghe, U. (2015). Tourism industry supply chain challenges in Anuradapura. Paper presented at the International Conference on Contemporary Management, Sri Lanka.

25. Nordström, J. (2005). Dynamic and stochastic structures in tourism demand modeling. Empirical Economics, 30(2), 379-392.

26. Pathmanathan, S. (1978). The Kingdom of Jaffna - Part 1. Colombo University of Peradeniya,.

27. Powell, R. B., Cuschnir, A., \& Peiris, P. (2009). Overcoming governance and institutional barriers to integrated coastal zone, marine protected area, and tourism management in Sri Lanka. Coastal Management, 37(6), 633-655.

28. Rasmussen, P., Muir-Cochrane, E., \& Henderson, A. (2012). Document analysis using an aggregative and iterative process. International Journal of Evidence - Based Healthcare, $10(2), 142-145$.

29. Ratnapala, R. (1999). Tourism in Sri Lanka: The social Impact. Ratmalana: Sarvodaya Vishva Lekha.

30. Remler, D. K., \& Van Ryzin, G. G. (2010). Research methods in practice: Strategies for description and causation: Sage Publications.

31. Reeves, K., \& Sivesan, S. (2017). Tourism, history, identity, and community resilience in the world heritage city of Kandy, Sri Lanka. In J. Cheer \& A. A. Lew (Eds.), Tourism, Resilience and Sustainability, Adapting to Social, Political and Economic Change. UK: Routledge.

32. Richter, L. K. (1999). After political turmoil: The lessons of rebuilding tourism in three Asian countries. Journal of travel research, 38(1), 41-45.

33. Ritchie, J., \& Spencer, L. (2002). Qualitative data analysis for applied policy research. In A.Bryman \& R.G.Burgess (Eds.), The qualitative researcher's companion (pp. 305-329). NewYork: Routledge. 
34. Robinson, L. J., J. K. (2008). Post-disaster community tourism recovery: the tsunami and Arugam Bay, Sri Lanka. Disasters, 32(4), 631-645.

35. Samaranayake, H. (2012). Lifetime in tourism. Sri Lanka: Vijitha Yapa Bookshop.

36. Samaranayake, H., Lantra, N., \& Jayawardena, C. (2013). Forty six years of organised tourism in Sri Lanka (1966-2012). Worldwide Hospitality and Tourism Themes, 5(5), 423-441.

37. Siriweera, W. (2002). History of Sri Lanka: from earliest times up to the sixteenth century. Colombo: Dayavamsa Jayakodi Saha Samagama.

38. Sitrampalam, S. (2005). The Tamils of Sri Lanka: The Historical Roots of Tamil Identity. In F. a. B. Klem (Ed.), Dealing with Diversity, Sri Lankan Discourses on Peace and Conflict (pp. 231-273). Hague: Netherlands The Netherlands Institute of International Relations Clingendael.

39. Snape, D., \& Spencer, L. (2003). The foundations of qualitative research. In R. Jane \& L. Jane (Eds.), Qualitative research practice: A guide for social science students and researchers (Vol. 11).

40. Sivesan, S. (2012). Changes in tourism trends in Sri Lanka. Management Focus, 12-23.

41. Sri Lanka Tourism Development Authority. (2016). Monthly Statistical Bulletins -2015. http://www.sltda.1k/node/704: Sri Lanka Tourism Development Authority.

42. Sri Lanka Tourism Promotion Bureau. (2011). Sri Lanka's Ramayana Trail :Visist the ancient sites of epic eternal. Colombo: Sri Lanka Promotion Bureau. 